See discussions, stats, and author profiles for this publication at: https://www.researchgate.net/publication/272113468

\title{
Effect of Wood Moisture Content in Edge Glued Panel Bonding for Furniture Industry: Analysis of Shear-Stress and Rupture in Bondline
}

Article · September 2014

DOI: 10.4028/www.scientific.net/AMR.1025-1026.227

\section{CITATION}

6 authors, including:

Juliana Cortez Barbosa

São Paulo State University

45 PUBLICATIONS 41 CITATIONS

SEE PROFILE

Bruno Santos Ferreira

São Paulo State University

18 PUBLICATIONS 18 CITATIONS

SEE PROFILE

Some of the authors of this publication are also working on these related projects:

Timber Forest Products and Industries View project

Centro de Capacitação Tecnológica em Bambu View project

\section{READS}

60

(8) Sristiane Inácio de Campos

39 PUBLICATIONS 61 CITATIONS

SEE PROFILE

Victor De Araujo

Research Group on Development of Lignocellulosic Products (LIGNO), Itapeva, Br... 60 PUBLICATIONS 63 CITATIONS

SEE PROFILE 


\title{
Effect of Wood Moisture Content in Edge Glued Panel Bonding for Furniture Industry: Analysis of Shear-Stress and Rupture in Bondline
}

\author{
Felipe Assunção de Araújo Ferraresi ${ }^{1, a}$, Juliana Cortez-Barbosa ${ }^{2, b}$, \\ Cristiane Inácio de Campos $^{2, c}$, Bruno Santos Ferreira ${ }^{3, d}$, \\ Victor Almeida De Araujo ${ }^{4, e^{*}}$ and Maristela Gava ${ }^{2, f}$
}

${ }^{1}$ Wood Industrial Engineer of Duratex. Rodovia Raposo Tavares, KM172,1, Itapetininga/SP, Brazil

${ }^{2}$ Assistant Professor Doctor of UNESP/Itapeva. Rua Geraldo Alckmin, 519, Itapeva/SP, Brazil

${ }^{3}$ Engineer and Doctoral Student of UNESP/Itapeva. Rua Geraldo Alckmin, 519, Itapeva/SP, Brazil ${ }^{4}$ Engineer and Master's Student of ESALQ/USP. Avenida Pádua Dias, 11, Piracicaba/SP, Brazil

\begin{abstract}
afferraresi@gmail.com, bjucortez@itapeva.unesp.br, 'cristiane@itapeva.unesp.br, dbrunosferreira88@gmail.com, engim.victor@yahoo.de (Corresponding Author), 'mgava@itapeva.unesp.br
\end{abstract}

Keywords: Furniture industry, EGP, Wood moisture, PVA adhesives.

\begin{abstract}
The objective of this article was to study the influence of the Pinus taeda wood moisture content to the production of EGP (Edge Glued Panel) in the bonding stage, using PVA adhesive. It was analyzed the joint resistances through shear-stress tests and rupture in the bondline. The wood moisture classes adopted to the panels were: "A" ( [8\%, 9\%[ ), "B" ( [9\%, 10\%[ ), "C" ( [10\%, $11 \%[$ ), "D" ( $[11 \%, 12 \%[$ ) e "E" ( [12\%, 13\%[ ). After the panel production, it was sawn the specimens for the resistance shear in the bondline tests by traction. The tests results showed that it was statistically significant differences to the values of rupture tensions between A class and B, C, $\mathrm{D}$ and $\mathrm{E}$ classes. The wood medium rupture presented a tendency to reduce with the moisture increase, and the total rupture in the bondline presented a small tendency of a less number of occurrences with the rupture tension increases.
\end{abstract}

\section{Introduction}

Brazilian furniture industry is among the most important segments of manufacturing industry, not only by the importance of the value of its production, but also by generating of jobs within the domestic industry. In monetary values, the industry produced in 2009, US\$ 8.0 billion, which is equivalent to $1.3 \%$ of Brazilian manufacturing industry [1].

Among the products derived from wood of great utilization in the furniture industries is the EGP, or Edge Glued Panel, which is defined as a set of pieces (lamellas) of wood glued laterally forming a wood panel [2].

The Brazilian EGP production from 1998 to 2007 increased from $255,000 \mathrm{~m}^{3}$ to $503,000 \mathrm{~m}^{3}$, having an annual growth rate of $7.8 \%$ and a total growth of $97.3 \%$ in the period. In relation to the consumption, it had a growth of $61.3 \%$ in the period and also $5.5 \%$ year-on-year [3].

There are some factors that may influence the bonding of lamellas, where Frihart and Hunt [4] cite three main factors:

a) The first is the surface of the wood, which it should be smooth, flattened and free of machining marks or other irregularities, including "marks" of planner, crushed parts, splinters and slivers. The surface should not be polished, exuded, greasy and or dirty. Therefore, the physical and chemical conditions of surfaces are extremely important for a successful outcome, as by adhesive bonding is the joining surfaces;

b) The second is the density and porosity of the wood, considering woods of high density of greater difficulty of bonding that low density, because they have thicker cell walls and smaller cell lumen, impeding the penetration of the adhesive. With respect to the porosity is the same, where 
less porous woods have greater resistance to penetration of adhesive than more porous woods, thus it has a lower bonding strength;

c) Third factor is the moisture content of the wood, which according to Currier [5] affects the flow, transfer and penetration ability of the adhesive. Very low moisture contents reduce the flow and the penetration of the adhesive into the wood, damaging the bond strength, while high moisture content often leads to excessive penetration of glue, resulting in a starved joint with inferior strength. The adhesive has great properties when its moisture content is among 6 and 14\% [4].

The objective of this work is to study the influence of moisture of Pinus taeda wood for the EGP production at the time of its bonding with PVA (polyvinyl acetate), analyzing the resistances of joints made in tests of tensile and shear bond strength and the percentage of rupture in bondline.

\section{Materials and Methods}

For adhesion tests, pieces of wood of Pinus taeda were applied, totally free of defects as pitch, cracks, etc. The adhesive was the polyvinyl acetate (PVA) - EZ-1 Multibond, Franklin International - applied with a roller process. The determination of wood moisture from lamellas (slats) was performed with the utilization of the moisture-meter for contact of Marrari (model M-51). The pressing of panels was realized in a press of high-frequency, of Metrisa manufacturer. The rupture tests were performed on a universal test machine of EMIC (model DL-2000). The tests were based on North-American standard ASTM D 5572 [6], which comments topics of adhesives applied in bonding joints of non-structural lumber products, and ASTM D 5751 [7] which remarks of the adhesives applied in laminar unions of non-structural lumber products.

Wood selection. The wooden slats (lamellas) were separated according to their moisture contents, indicated by the moisture meter. Three measurements were performed in each slat, and also it was obtained the average of these values, which is separated by classes shown in Table 1 .

Table 1 Adopted moisture classes of wood.

\begin{tabular}{|c|c|}
\hline Class & Average of Moisture Content [\%] \\
\hline A & $8 \leq \mathrm{u}<9$ \\
\hline B & $9 \leq \mathrm{u}<10$ \\
\hline C & $10 \leq \mathrm{u}<11$ \\
\hline D & $11 \leq \mathrm{u}<12$ \\
\hline E & $12 \leq \mathrm{u}<13$ \\
\hline
\end{tabular}

Manufacturing of Panels. EGP panels were produced from slats (lamellas) of Pinus taeda of 19 millimeters of thickness, $34 \mathrm{~mm}$ of width and $350 \mathrm{~mm}$ of length. Each panel was composed of 12 slats of the same class of moisture (Table 1) totalizing the size of the panels in 408 millimeters of width, 350 millimeters of length and 19 millimeters of thickness. All panels are made in a single pressing step, in order to maintain constant the variables of: pressing time of 150 seconds, lateral pressure of 5.0 MPa, table-machine pressure (superior) of $5.5 \mathrm{MPa}$, anode electric current of 4,4 Ampères, glue weight (grammage) of $219, \mathrm{~g} / \mathrm{m}^{2}$, and press area of $83.7 \%\left(4.095 \mathrm{~m}^{2}\right)$.

The apparent density of wood was measured for each moisture class, using a weighing scale and a caliper rule, obtaining an average value for each class using equation 1 :

$$
\rho_{\mathrm{ap}}=\mathrm{m}_{\mathrm{t}} /(\mathrm{n} \times 1 \times \mathrm{e} \times \mathrm{c})
$$

Where:

- $\rho_{\mathrm{ap}}$ is the average bulk density;

- $\mathrm{m}_{\mathrm{t}}$ is the total mass of selected samples;

- $\mathrm{n}$ is the number of samples weighed;

- 1 is width of the sample; 
- $\mathrm{e}$ is thickness of the sample;

- $\mathrm{c}$ is the length of the sample.

Specimens Preparation. The preparation of the samples for the tensile shear by traction on the universal machine was performed 24 hours after gluing of EGP panels, firstly calibrating them to a 16-mm-thickness, in order to correct the variations of height of slats caused during the bonding process. After this step, the panels were cut as a common board, and lastly the samples were sawn.

Evaluation of the Areas of Bonding Failures. To quantify the failure of wood in the glued joint was used iodine, which is applied to wood glued facilitating the visualization of the presence of the adhesive, marking it in a dark pattern. With a caliper measured the approximate dimensions of the areas of bonding failure in wood and they were expressed in percentages, on a scale of $5 \%$ by $5 \%$.

Test Conditions. The specimens were subjected to constant deformations of 20 millimeter/ minutes and fixed in the universal machine. As the surfaces of the specimens had a good finishing, it was necessary making rough the contact surface to prevent the sample sliding in the grips of the universal test machine. So, it was used a circular-saw to scratch the surface, leaving it rougher.

Statistical Design. The test results were statistically analyzed by of an analysis of variance and Tukey test at $95 \%$ of probability with Minitab software. It was wished to know if the average values of rupture tensions and the failure in wood are statistically different among the adopted classes.

\section{Results and Discussions}

Tests per Class. The Table 2 shows the results of the tests of modulus of rupture (average values) and also of rupture in bondline (average), along with the average bulk density and the number of samples of each one of the moisture classes adopted. With the values in Table 2, it can be observed a trend of an increasing of the resistance of bondline with the increasing of the moisture content up to $12 \%$, although adhesive manufacturers recommend lower values. It was verified that the resistance is related more closely with the value of the density of wood in each class.

Table 2 Tests results for the classes of moisture.

\begin{tabular}{|l|c|c|c|c|c|}
\hline \multicolumn{1}{|c|}{ Classes of moisture } & $\mathrm{A}$ & $\mathrm{B}$ & $\mathrm{C}$ & $\mathrm{D}$ & $\mathrm{E}$ \\
\hline Values of moisture & $8 \leq \mathrm{u}<9$ & $9 \leq \mathrm{u}<10$ & $10 \leq \mathrm{u}<11$ & $11 \leq \mathrm{u}<12$ & $12 \leq \mathrm{u}<13$ \\
\hline $\begin{array}{l}\sigma_{\text {rupture }} \text { average } \\
{\left[\mathrm{kgf} / \mathrm{cm}^{2}\right]}\end{array}$ & 56.68 & 72.50 & 73.65 & 82.88 & 76.83 \\
\hline $\begin{array}{l}\text { Rupture in Bondline } \\
{[\%]}\end{array}$ & 94 & 86 & 78 & 58 & 33 \\
\hline$\rho_{\text {ap }}$ average $\left(\mathrm{g} / \mathrm{cm}^{3}\right)$ & 0.462 & 0.593 & 0.501 & 0.579 & 0.561 \\
\hline
\end{tabular}

So two graphs were plotted to show the relations of the rupture in bondline and moisture with the modulus of rupture (Figure 1) and the bulk density (Figure 2), respectively. 


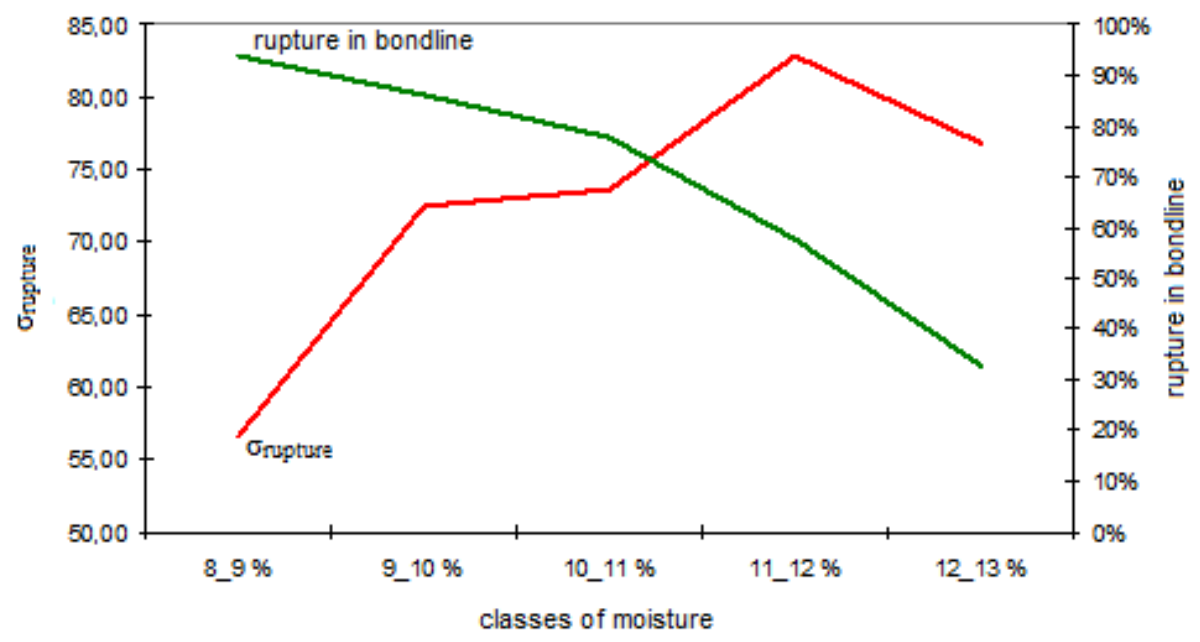

Fig. 1 Relations among moisture, modulus of rupture and average rupture in bondline.

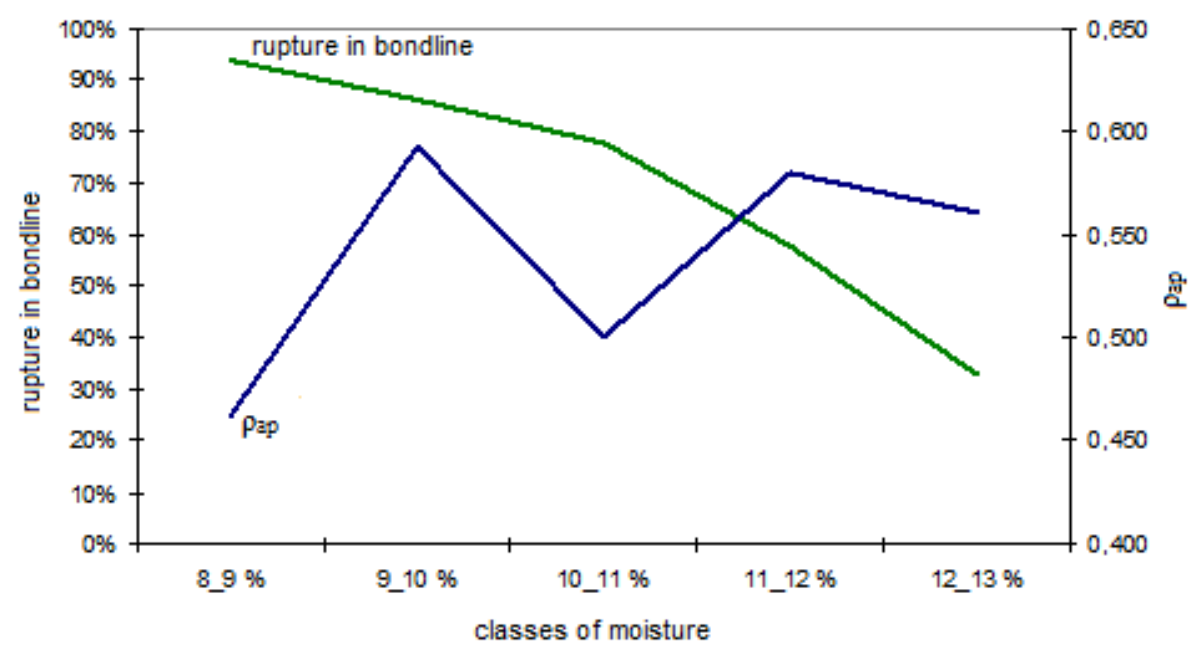

Fig. 2 Relations among moisture, bulk density and average rupture in bondline.

Resistances According to the Class. For the statistical analysis of the stresses, it was considered a normal distribution, fact which can be observed in the Figure 3, with the distributions of the values, similar as a normal curve. It shows the stress of rupture histogram of all the samples. The Table 3 shows the values treated with the Tukey test, concluding that the values of the stress of rupture of Class A are statistically different from other instances. The other classes do not differ among themselves. So, in this case, it can be said then that Class A had lower shear resistance values in the bondline in relation to other classes, but it is impossible to state if this lower level is caused by the moisture or due to the low density of the substrate. 

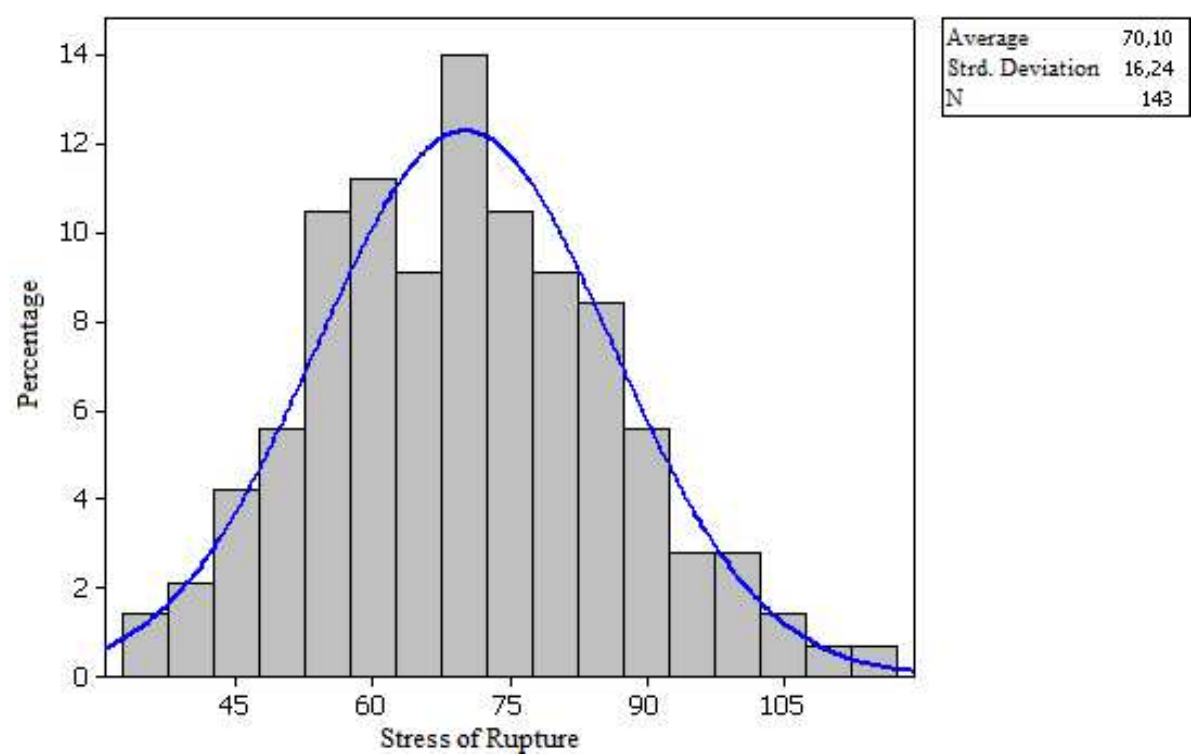

Fig. 3 Stress of rupture of all the samples.

Table 3 Average values of shear resistance, separated by classes.

\begin{tabular}{|c|c|c|}
\hline Class & Moisture [\%] & Shear resistance average [kgf/cm $\left.{ }^{2}\right]$ \\
\hline A & $8 \leq \mathrm{u}<9$ & $56,7 \mathrm{a}$ \\
\hline $\mathrm{B}$ & $9 \leq \mathrm{u}<10$ & $72,6 \mathrm{~b}$ \\
\hline $\mathrm{C}$ & $10 \leq \mathrm{u}<11$ & $73,7 \mathrm{~b}$ \\
\hline $\mathrm{D}$ & $11 \leq \mathrm{u}<12$ & $82,9 \mathrm{~b}$ \\
\hline $\mathrm{E}$ & $12 \leq \mathrm{u}<13$ & $76,9 \mathrm{~b}$ \\
\hline
\end{tabular}

\section{Conclusions}

There were differences of the values studied for the classes of wood moisture for both the shear stress by traction as for the rupture in bondline. The resistance values differ statistically, with a Class A with the lowest average of $56.7 \mathrm{kgf} / \mathrm{cm}^{2}$, but other classes have values that can not be considered different. It was observed that the average resistance has tended to be greater when the moisture increases. The resistances showed a close relationship with the average bulk density of the class. The average resistance was greater for the Class D, with a range of moistures between 11 and $12 \%$, increasing the resistance value up to this point and decreasing in other class, indicating the tendency for very low and very high moistures are not favorable to bonding in these conditions.

The average rate of rupture in bondline in the glued joint showed a tendency to decrease with the increasing of the moisture content of wood. In relation to the stress of rupture, the total rupture in bondline presented a decrease in the number of occurrences with the increasing of the tension. The total rupture of bonding (100\%) occurred in a greater proportion in classes A, B and C, respectively. The D and E classes showed low levels of total rupture in bondline, indicating higher proportions of ruptures, among 45 and 55\%, due to higher moisture content.

The production of EGP panels can be compromised if factors such as wood moisture content in the bonding process are not taken into consideration. A product of quality "for export" should not be overlooked in the bonding process of a panel, as it may increase the rate of product defects.

Although panels with bonding defects can be detected even in the productive stage, in other words, before the product reaches the final consumer, the quality deviations generate costly and inefficient spending to the manufacturers, with reworks, higher residual generation, loss of operating-machine time and other factors. The present paper sought to show the relationship between bonding of wood and its moisture; however, the variable density of wood was significantly interfering in the results. 


\section{References}

[1] ABIMOVEL - Brazilian Association of Furniture Industries: Panorama of the Furniture Industry 2008-2009, ABIMOVEL, (2011), http://www.abimovel.com/

[2] ABIMCI - Brazilian Association of Industry of Mechanically Manufactured Wood: Wood Products, ABIMCI, (2004), http://www.abimci.com.br/pt/

[3] ABIMCI - Brazilian Association of Industry of Mechanically Manufactured Wood: Sector study 2008, ABIMCI, (2008), http://www.abimci.com.br/pt/

[4] R.C. Frihart and G.C. Hunt: Adhesives with Wood Materials - Bond Formation and Performance, in: Forest Products Laboratory (Ed.): Wood Handbook - wood as an engineering material, Centennial Edition, Forest Products Laboratory, (2010), 24 p.

[5] R.A. Currier: The importance of lumber seasoning in wood gluing, Oregon Forest Research Center, (1961), 4 p. ir.library.oregonstate.edu/dspace/bitstream/1957/4872/1/Importance_Lumber_ocr.pdf

[6] ASTM - American Society for Testing and Materials: ASTM D 5572 - Standard Specification for Adhesives Used for products not in Ensambladuras of Structural Lumber, (1995), 17 p.

[7] ASTM - American Society for Testing and Materials: ASTM D 5751 - Standard Specification for Adhesives Used in Unions Laminar Products for Nonstructural Lumber, (1991), 11 p. 